\title{
Effect of Luminal Sodium Concentration on Bicarbonate Absorption in Rat Jejunum
}

\author{
Kenneth A. Hubei \\ From the Department of Medicine, University of Iowa, Iowa City, Iowa 52242
}

\begin{abstract}
A B S T R A C T An exchange of $\mathrm{Na}^{+}$for $\mathrm{H}^{+}$has been proposed to explain why jejunal $\mathrm{Na}^{+}$absorption is influenced by luminal concentrations of $\mathrm{H}^{+}$and $\mathrm{HCO}_{3}^{-}$. We studied the influence of luminal $\mathrm{Na}^{+}$concentration on net $\mathrm{HCO}_{3}^{-}$absorption by perfusing rat jejunum in vivo. When $\mathrm{Na}^{+}$was omitted from the perfusion fluid, $\mathrm{HCO}_{3}{ }^{-}$ absorption diminished by a fixed amount over a range of initial $\mathrm{HCO}_{3}^{-}$concentrations of 15 to $80 \mathrm{mM}$. This change was not caused by alterations in transmural PD or direction of water movement. Because the rate of $\mathrm{HCO}_{3}{ }^{-}$absorption decreased as the luminal $\mathrm{HCO}_{3}{ }^{-}$concentration lessened, $\mathrm{Na}^{+}$-dependent $\mathrm{HCO}_{3}^{-}$absorption accounted for an increasing percent of total absorption as the luminal concentration of $\mathrm{HCO}_{3}^{-}$diminished.
\end{abstract}

The effect of $\mathrm{Na}^{+}$on $\mathrm{HCO}_{3}^{-}$absorption is mediated, at least in part, by $\mathrm{H}^{+}$secretion, because luminal $\mathrm{CO}_{2}$ production (manifested by luminal $\mathrm{PCO}_{2}$ ) dimished as $\mathrm{HCO}_{3}^{-}$absorption decreased. The changes in $\mathrm{PCO}_{2}$ are caused by reaction of $\mathrm{H}^{+}$with $\mathrm{HCO}_{3}^{-}$in the luminal fluid because luminal $\mathrm{PCO}_{2}$ is augmented by the presence of $\mathrm{HCO}_{3}{ }^{-}$and is diminished by addition of phosphate or Tris buffer.

Whether all $\mathrm{H}^{+}$secretion requires luminal $\mathrm{Na}^{+}$cannot be determined with these experimental techniques because mucosal permeability to $\mathrm{Na}^{+}$and the unstirred layer make it impossible to eliminate $\mathrm{Na}^{+}$ions from the luminal cell surface. The nature of the mechanism for $\mathrm{HCO}_{3}{ }^{-}$transport that is not sodium dependent remains to be determined.

\section{INTRODUCTION}

Parsons proposed that hydrogen ion secretion caused bicarbonate absorption in the rat jejunum, and speculated that $\mathrm{H}^{+}$secretion is associated in part with processes of sodium absorption (1). Studies of the perfused

This work was reported in part in Gastroenterology. 1972. $62: 764$.

Received for publication 6 December 1972 and in revised form 14 August 1973. human jejunum also suggest that bicarbonate absorption is initiated by an exchange of hydrogen ions for sodium ions. The hydrogen ions react with bicarbonate ions to form carbon dioxide which then diffuses from the lumen (2). Two observations suggest that jejunal sodium absorption is influenced by luminal $\mathrm{H}^{+}$concentration: the addition of bicarbonate to saline perfusion solutions reduces the concentration of hydrogen ions and makes it possible for sodium to be absorbed against electrochemical gradients (3), and an increase in hydrogen ion concentration reduces the rate of sodium absorption (4).

If hydrogen and sodium ion transport are mutually dependent, then reduction of luminal sodium concentration should reduce the rate of hydrogen ion transport and bicarbonate absorption. The following studies examine that hypothesis.

\section{METHODS}

Male Holtzman rats were fasted overnight and anesthetized by injecting pentobarbital $(50 \mathrm{mg} / \mathrm{kg})$ into the peritoneal cavity. A $25-\mathrm{cm}$ segment of proximal jejunum was cannulated at each end, washed with $15 \mathrm{ml}$ of warm saline, and flushed with air. A tracheostomy tube was inserted.

Pairs of solutions were perfused once through the segment with a syringe infusion pump at the rate of $0.41 \mathrm{ml} /$ min during two successive 30 -min periods. The input syringe, intestine, and collection syringe attached to the distal cannula formed a closed system and minimized leakage of $\mathrm{CO}_{2}$. The order of perfusion of the solutions was alternated in successive rats in all studies. Before each perfusion period, the intestinal lumen was washed with the solution to be perfused and was flushed with gas. At the end of each period, collection syringes were removed and capped, and any fluid remaining in the segment was flushed with gas and discarded. After the second period, the jejunum was removed, stripped of mesentery, and weighed.

With the exception of solutions 1 and 10 (Table I), all solutions were gassed with a mixture of $\mathrm{O}_{2}$ and $5-6 \%$ $\mathrm{CO}_{2}$ (gas) and had an initial $\mathrm{pH}$ of about 7.4. Polyethylene$\left[1,2{ }^{14} \mathrm{C}\right]$ glycol $\left.\left({ }^{14} \mathrm{C}\right] \mathrm{PEG}\right){ }^{1} 1.25 \mu \mathrm{Ci} / \mathrm{dl}$ was used as a

${ }^{1}$ Abbreviations used in this paper: $\left[{ }^{14} \mathrm{C}\right] \mathrm{PEG}$, polyethylene- $\left[1,2-{ }^{14} \mathrm{C}\right] \mathrm{glycol} ; \mathrm{gWW}$, jejunum wet weight in grams. 
TABLE I

Composition of Perfusion Fluids (mM)

\begin{tabular}{|c|c|c|c|c|c|c|c|c|c|}
\hline Solution & $\mathrm{Na}$ & $\mathrm{K}$ & Choline & $\mathrm{Cl}$ & $\mathrm{HCO}_{3}$ & Iseth. & Mann. & Tris & $\mathrm{PO}_{4}$ \\
\hline 1 & 145 & 5 & - & 125 & 25 & - & 25 & & \\
\hline 2 & 25 & 5 & 120 & 125 & 25 & - & 30 & & \\
\hline 3 & 145 & 5 & - & 125 & 25 & - & 80 & & \\
\hline 4 & 145 & 5 & - & 5 & 25 & 120 & 25 & & \\
\hline 5 & 140 & 5 & -- & 130 & 15 & - & 34 & & \\
\hline 6 & - & 15 & 130 & 130 & 15 & - & 41 & & \\
\hline 7 & - & 30 & 120 & 125 & 25 & - & 30 & & \\
\hline 8 & 140 & 5 & - & 65 & 80 & - & 37 & & \\
\hline 9 & - & 80 & 65 & 65 & 80 & - & 37 & & \\
\hline 10 & 145 & 5 & - & 150 & - & - & - & & \\
\hline 11 & 145 & 5 & - & 130 & 20 & - & 25 & & \\
\hline 12 & 145 & 5 & - & 70 & 80 & - & 28 & & \\
\hline 13 & 140 & 5 & - & 125 & 20 & - & 5 & 20 & \\
\hline 14 & 140 & 5 & - & 125 & 20 & - & 35 & & \\
\hline 15 & 140 & 5 & - & 105 & 20 & - & 57 & & 20 \\
\hline
\end{tabular}

nonabsorbable marker to permit calculation of net water movement (5). Except for the hypertonic solution, the osmolality of all perfusion solutions was similar to that of rat plasma, 303-305 mosmol/ $\mathrm{kg} \mathrm{H}_{2} \mathrm{O}$.

The $\mathrm{pH}$ and $\mathrm{PCO}_{2}$ of the luminal fluid were determined soon after collection with a capillary $\mathrm{pH}$ electrode and $\mathrm{PCO}_{2}$ electrode designed for small samples (Instrumentation Laboratory, Inc., Lexington, Mass.). Bicarbonate was calculated with the Henderson-Hasselbalch equation using a $\mathrm{pK}^{\prime}$ of 6.1. Sodium and potassium concentrations were measured with a flame photometer and chloride was determined with a coulometric chloridometer. The concentration of $\left[{ }^{14} \mathrm{C}\right] \mathrm{PEG}$ (counts per minute/milliliter) was measured with a scintillation counter. The asmolality (milliosmoles/kilogram) of perfusion fluids was measured by the method of freezing point depression with an Advanced Osmometer (Advanced Instruments, Needham Heights, Mass.).

"Initial" concentrations of ions and of $\left[{ }^{14} \mathrm{C}\right] \mathrm{PEG}$ were measured in samples of fluid obtained from the input syringes and samples of fluid for "final" determinations were obtained from the collection syringes after each collection period. Fluid remaining in the jejunum was discarded.

Net fluxes of ions and water were calculated as follows :

$$
\begin{aligned}
J_{\text {net }} \text { ion } & =\mathrm{V}\left(\operatorname{ion}_{f} \frac{\mathrm{PEG}_{i}}{\mathrm{PEG}_{f}}-\text { ion }_{i}\right) \mathrm{gWW}^{-1}, \\
J_{\text {net }} \mathrm{H}_{2} \mathrm{O} & =\mathrm{V}\left(\frac{\mathrm{PEG}_{i}}{\mathrm{PEG}_{f}}-1\right) \mathrm{gWW}^{-1}
\end{aligned}
$$

Ion ${ }_{t}$ and ion $_{f}$ are the concentrations of the ion (micromoles/milliliter) measured in the initial and final samples; $\mathrm{PEG}_{\text {; }}$ and $\mathrm{PEG}_{\text {f }}$ are the specific activities of $\left[{ }^{14} \mathrm{C}\right] \mathrm{PEG}$ (counts per minute/milliliter) measured in the initial and final samples. $\mathrm{V}$ is the volume (milliliter) of perfusion fluid pumped into the segment in $30 \mathrm{~min} ; \mathrm{gWW}$ is the wet weight of the jejunum in grams. Thus, $J_{\text {netion }}$ is expressed as micromoles $\times(30 \mathrm{~min})^{-1} \times \mathrm{gWW}^{-1}$, and $J_{\text {net }} \mathrm{H}_{2} \mathrm{O}$ is expressed as milliliters $\times(30 \mathrm{~min})^{-1} \times \mathrm{gWW}^{-1}$.

Changes in the $\mathrm{PCO}_{2}$ of the luminal fluid are expressed as $\Delta \mathrm{PCO}_{2}$ and were calculated by subtracting the initial
$\mathrm{PCO}_{2}$ from the final $\mathrm{Pco}_{2}$, i.e., $\Delta \mathrm{PCO}_{2}=$ final $\mathrm{PCO}_{2}-$ initial $\mathrm{PCO}_{2}$.

Three different groups of six rats each were used to determine transmural electrical potential difference (PD) when the following pairs of solutions were perfused (Table I) : $\mathrm{Na}^{+} 145$ vs. $\mathrm{Na}^{+} 25$ (solutions 1 and 2), isotonic vs. hypertonic (solutions 1 and 3 ), and $\mathrm{Na}^{+} 145$ vs. $\mathrm{Na}^{+}$isethionate (solution 1 and 4). A group of eight rats was used to determine $\mathrm{PD}$ when solutions with and without bicarbonate were perfused (solutions 1 and 10). Bridges of saturated $\mathrm{KCl}$ in agar were used. One bridge contacted the fluid perfusing the intestinal lumen and the other was placed in the peritoneal cavity. Electrical contact with a sensitive voltmeter was made through calomel half-cells. The voltmeter was read every $3 \mathrm{~min}$ for $30 \mathrm{~min}$ and the mean of the 10 values was calculated. The studies of PD and transport were not performed concurrently.

The signs preceding the net flux measurements indicate movement into $(+)$ or out of $(-)$ the lumen.

The statistical significance of differences between means was determined with the $t$ test for paired samples.

\section{RESULTS}

Study 1: effect of reduction in sodium concentration of perfusion fluid (Table II)

Perfusion solutions 1 and 2 (Table I). $N=6$. To determine the effect of luminal sodium concentration on bicarbonate absorption, the jejunum was perfused with two solutions whose mean measured sodium concentrations were $143 \mathrm{mM}$ and $30 \mathrm{mM}$. When the sodium concentration was reduced, less $\mathrm{HCO}_{3}^{-}$was absorbed, ${ }^{2} \mathrm{pH}$ did not fall as far, and $\mathrm{PCO}_{2}$ rose less. Sodium was secreted instead of absorbed, chloride secretion increased, and potassium absorption was enhanced. There was also an apparent absorption of anions in excess of cations,

${ }^{9}$ In this discussion, absorption denotes a net loss from the lumen, and secretion denotes a net increase in the lumen. 
TABLE II

Effect of Low Luminal Sodium Concentration on the Net Movement of Electrolytes and Water, and the Magnitude of Luminal $\mathrm{P}_{\mathrm{CO}_{2}}$ and Transmural

Electrical Potential Difference

$(P D)(N=6)$

\begin{tabular}{|c|c|c|c|}
\hline \multirow{2}{*}{$\begin{array}{l}\text { Dependent } \\
\text { variable }\end{array}$} & \multicolumn{2}{|c|}{$\begin{array}{l}\text { Mean } \mathrm{Na}^{+} \text {concentration of } \\
\text { perfusion fluid }\end{array}$} & \multirow[b]{2}{*}{$P$} \\
\hline & $143 \mathrm{mM}$ & $30 \mathrm{mM}$ & \\
\hline \multicolumn{4}{|l|}{$\mathrm{HCO}_{3}{ }^{-*}$} \\
\hline $\begin{array}{l}\mu m o l \\
m M\end{array}$ & $\begin{array}{r}-105 \pm 13 \\
20.4 \pm 0.7\end{array}$ & $\begin{array}{l}-84 \pm 22 \\
21.9 \pm 0.8\end{array}$ & $\begin{array}{l}<0.05 \\
<0.05\end{array}$ \\
\hline \multicolumn{4}{|l|}{$\mathrm{pH}$} \\
\hline $\begin{array}{l}\text { Initial } \\
\Delta\end{array}$ & $\begin{array}{r}7.42 \pm 0.02 \\
-0.30 \pm 0.02\end{array}$ & $\begin{array}{r}7.44 \pm 0.01 \\
-0.24 \pm 0.02\end{array}$ & $\begin{array}{l}<0.01 \\
<0.01\end{array}$ \\
\hline \multicolumn{4}{|l|}{$\mathrm{PCO}_{2}$} \\
\hline $\begin{array}{l}\text { Initial } m m ~ H g \\
\Delta m m ~ H g\end{array}$ & $\begin{array}{l}38 \pm 1 \\
15 \pm 2\end{array}$ & $\begin{array}{l}38 \pm 1 \\
11 \pm 3\end{array}$ & $\begin{array}{c}\mathrm{NS} \\
<0.05\end{array}$ \\
\hline \multicolumn{4}{|l|}{$\mathrm{H}_{2} \mathrm{O}$} \\
\hline$m l$ & $-0.28 \pm 0.20$ & $0.24 \pm 0.26$ & $<0.001$ \\
\hline \multicolumn{4}{|l|}{ PD } \\
\hline$m V$ & $-5.2 \pm 1.6$ & $3.5 \pm 1.0$ & $<0.001$ \\
\hline \multicolumn{4}{|l|}{$\mathrm{Na}^{+}$} \\
\hline $\begin{array}{l}\mu m o l \\
m M\end{array}$ & $\begin{array}{c}-102 \pm 15 \\
143 \pm 1\end{array}$ & $\begin{array}{c}119 \pm 21 \\
30 \pm 1\end{array}$ & $\begin{array}{l}<0.001 \\
<0.001\end{array}$ \\
\hline \multicolumn{4}{|l|}{$\mathrm{K}^{+}$} \\
\hline $\begin{array}{l}\mu m o l \\
m M\end{array}$ & $\begin{array}{c}0.47 \pm 1.75 \\
5.1 \pm 0.1\end{array}$ & $\begin{array}{c}-7.28 \pm 1.98 \\
4.7 \pm 0.1\end{array}$ & $\begin{array}{l}<0.01 \\
<0.001\end{array}$ \\
\hline \multicolumn{4}{|l|}{$\mathrm{Cl}^{-}$} \\
\hline $\begin{array}{l}\mu m o l \\
m M\end{array}$ & $\begin{array}{l}24.1 \pm 26.5 \\
128 \pm 2\end{array}$ & $\begin{array}{l}109 \pm 27.3 \\
128 \pm 1\end{array}$ & $\begin{array}{l}<0.001 \\
\text { NS }\end{array}$ \\
\hline
\end{tabular}

* For measurements of net movement and electrolytes and water, signs indicate movement into $(+)$ or out of $(-)$ the lumen. Rates of net transport of water and electrolytes are expressed as the quantity $\times(30 \mathrm{~min})^{-1} \times($ gram wet $\mathrm{wt}$ of intestine $)^{-1}$. The mean concentration of ions for the perfusion period is expressed in millimoles/liter. Values shown are the mean $\pm \mathrm{SD}$. The sign of the $\mathrm{PD}$ is the polarity of the jejunal lumen.

and this is probably because choline is not accounted for in the table. The charge balances suggest that appreciable amounts of choline were absorbed.

When the luminal $\mathrm{Na}^{+}$concentration was reduced, two factors that could influence net movement of $\mathrm{HCO}_{3}{ }^{-}$ and $\mathrm{H}^{+}$changed significantly: the transmural $\mathrm{PD}$ became $8.7 \mathrm{mV}$ more positive in the lumen, and the net movement of water was into the lumen. The influence of these two factors on bicarbonate absorption was estimated in studies 2 and 3.
Study 2: effect of direction of water movement (Table III)

Perfusion solutions 1 and 3 (Table I). $N=6$. When the osmolality of the perfusion we increased from 305 mosmol $/ \mathrm{kg}$ to $350 \mathrm{mosmol} / \mathrm{kg}$ by adding mannitol, water moved into rather than out of the lumen, and the mean rate of movement of water into the lumen was greater than when the low sodium solution was perfused in study 1. However, the direction of water movement did not significantly affect the net movement of ions, the PD, or the final $\mathrm{PCO}_{2}$ of the perfusion fluid.

\section{Study 3: effect of transmural PD (Table IV)}

Perfusion solutions 1 and 4 (Table I). $N=6$. When the solution containing sodium isethionate was perfused, the luminal $\mathrm{PD}$ was $7.5 \mathrm{mV}$ more negative than

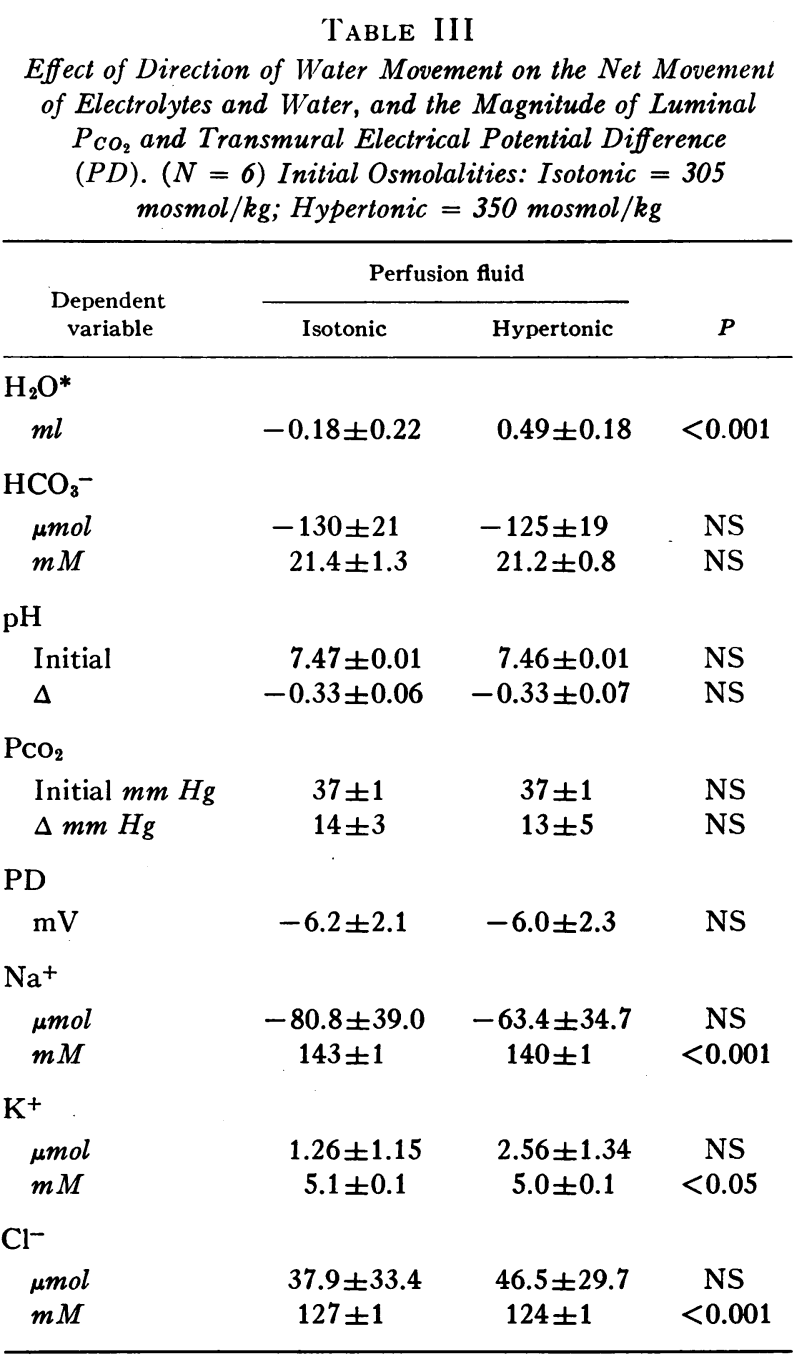

* See footnote to Table II. 
when sodium chloride was used. Sodium absorption decreased, chloride was secreted, and water moved into the lumen. However, the change in PD did not alter net movement of $\mathrm{HCO}_{s}^{-}$, the change in $\mathrm{pH}$, or the $\Delta$ $\mathrm{PCO}_{2}$.

Study 4: how omission of $\mathrm{Na}^{+}$from luminal fluid affects bicarbonate absorption when initial $\mathrm{HCO}_{3}-$ concentration of luminal fluid is varied (Table VA, B, and C)

Perfusion solutions 5 and 6, 1 and 7,8 and 9 (Table I). $N=8$ for each pair of perfusion fluids. When sodium was omitted from the perfusion fluid, sodium diffused into the lumen and raised the concentration in luminal fluid to about $10 \mathrm{mM}$ whether the initial concentration of $\mathrm{HCO}^{-}$was $15 \mathrm{mM}$ (Table VA), $25 \mathrm{mM}$ (Table VB), or $80 \mathrm{mM}$ (Table VC). Regardless of the initial $\mathrm{HCO}_{3}^{-}$concentration, $\mathrm{HCO}_{3}{ }^{-}$absorption decreased

TABLE IV

Effect of Change in Transmural Electrical Potential Differences Magnitude of Luminal $P_{C O}$. $(N=6) P D$ was Changed by Substituting Isethionate for Chloride in the Perfusion Fluid

\begin{tabular}{|c|c|c|c|}
\hline \multirow{2}{*}{$\begin{array}{c}\text { Dependent } \\
\text { variable }\end{array}$} & \multicolumn{2}{|c|}{ Perfusion fluid } & \multirow[b]{2}{*}{$P$} \\
\hline & Chloride & Isethionate & \\
\hline \multicolumn{4}{|l|}{ PD } \\
\hline$m V$ & $-6.9 \pm 2.1$ & $-14.4 \pm 2.7$ & $<0.02$ \\
\hline \multicolumn{4}{|l|}{$\mathrm{HCO}_{3}{ }^{-*}$} \\
\hline $\begin{array}{l}\mu m o l \\
m M\end{array}$ & $\begin{array}{c}-125 \pm 9 \\
21.8 \pm 1.9\end{array}$ & $\begin{array}{r}-125 \pm 17 \\
23.1 \pm 1.9\end{array}$ & $\begin{array}{c}\text { NS } \\
<0.001\end{array}$ \\
\hline \multicolumn{4}{|l|}{$\mathrm{pH}$} \\
\hline $\begin{array}{l}\text { Initial } \\
\Delta\end{array}$ & $\begin{array}{r}7.43 \pm 0.01 \\
-0.33 \pm 0.04\end{array}$ & $\begin{array}{r}7.46 \pm 0.02 \\
-0.33 \pm 0.05\end{array}$ & $\begin{array}{c}<0.02 \\
\text { NS }\end{array}$ \\
\hline \multicolumn{4}{|l|}{$\mathrm{P}_{\mathrm{CO}_{2}}$} \\
\hline $\begin{array}{l}\text { Initial } m m H g \\
\Delta m m ~ H g\end{array}$ & $\begin{array}{l}41 \pm 2 \\
15 \pm 3\end{array}$ & $\begin{array}{l}41 \pm 3 \\
14 \pm 3\end{array}$ & $\begin{array}{l}\text { NS } \\
\text { NS }\end{array}$ \\
\hline \multicolumn{4}{|l|}{$\mathrm{H}_{2} \mathrm{O}$} \\
\hline$m l$ & $-0.34 \pm 0.24$ & $0.10 \pm 0.12$ & $<0.01$ \\
\hline \multicolumn{4}{|l|}{$\mathrm{Na}^{+}$} \\
\hline $\begin{array}{l}\mu m o l \\
m M\end{array}$ & $\begin{array}{c}-98.6 \pm 39.9 \\
143 \pm 1\end{array}$ & $\begin{array}{c}-2.4 \pm 16.1 \\
144 \pm 1\end{array}$ & $\begin{array}{l}<0.001 \\
<0.05\end{array}$ \\
\hline \multicolumn{4}{|l|}{$\mathrm{K}^{+}$} \\
\hline $\begin{array}{l}\mu m o l \\
m M\end{array}$ & $\begin{array}{c}0.47 \pm 2.25 \\
5.1 \pm 0.1\end{array}$ & $\begin{array}{c}4.54 \pm 3.57 \\
5.1 \pm 0.1\end{array}$ & $\begin{array}{l}\text { NS } \\
\text { NS }\end{array}$ \\
\hline \multicolumn{4}{|l|}{$\mathrm{Cl}^{-}$} \\
\hline $\begin{array}{l}\mu m o l \\
m M\end{array}$ & $\begin{aligned}-22.7 & \pm 25.0 \\
126 & \pm 1\end{aligned}$ & $\begin{array}{c}134 \pm 21 \\
5.6 \pm 1\end{array}$ & $\begin{array}{l}<0.001 \\
<0.001\end{array}$ \\
\hline
\end{tabular}

* See footnote to Table II.
TABLE V

Effect of Low Luminal Sodium Concentration on the Net Movement of Bicarbonate, and on the Change in $p H$ and $\mathrm{PCO}_{2}$ of Perfusion Fluid When the Initial $\mathrm{HCO}_{3}$ - Concentration was $15 \mathrm{mM}(\mathrm{A})$, $25 m M(B)$, and $80 m M(C)$

(A)

\begin{tabular}{|c|c|c|c|c|}
\hline \multirow{2}{*}{$\begin{array}{c}(N=8) \\
\text { Dependent } \\
\text { variable }\end{array}$} & \multicolumn{2}{|c|}{ Mean luminal $\mathrm{Na}$ concentration } & \multirow[b]{2}{*}{$\Delta$} & \multirow[b]{2}{*}{$P$} \\
\hline & $138 \pm 2 \mathrm{mM}$ & $9.3 \pm 1.4 \mathrm{mM}$ & & \\
\hline \multicolumn{5}{|l|}{$\mathrm{HCO}_{3}^{-*}$} \\
\hline $\begin{array}{l}\text { umol } \\
\text { mean } m M\end{array}$ & $\begin{array}{c}-71.6 \pm 11.6 \\
12.4 \pm 0.5\end{array}$ & $\begin{array}{r}-40.8 \pm 8.3 \\
13.3 \pm 0.4\end{array}$ & $\begin{array}{r}30.8 \\
0.9\end{array}$ & $\begin{array}{l}<0.001 \\
<0.01\end{array}$ \\
\hline pH & & & & \\
\hline $\begin{array}{l}\text { Initial } \\
\Delta\end{array}$ & $\begin{array}{r}7.19 \pm 0.02 \\
-0.28 \pm 0.05\end{array}$ & $\begin{array}{r}7.20 \pm 0.01 \\
-0.20 \pm 0.04\end{array}$ & $\overline{0.08}$ & $\begin{array}{c}\text { NS } \\
<0.001\end{array}$ \\
\hline \multicolumn{5}{|l|}{$\mathrm{PCO}_{2}$} \\
\hline $\begin{array}{l}\text { Initial } m m \mathrm{Hg} \\
\Delta m m \mathrm{Hg}\end{array}$ & $\begin{array}{r}40.4 \pm 0.9 \\
9.5 \pm 1.4\end{array}$ & $\begin{array}{r}40.5 \pm 0.7 \\
7.6 \pm 1.6\end{array}$ & $\overline{1.9}$ & $\begin{array}{c}\text { NS } \\
<0.05\end{array}$ \\
\hline
\end{tabular}

(B)

Mean luminal Na concentration

$\begin{array}{lrrll} & 143 \pm 1 \mathrm{mM} & 8.9 \pm 1.4 \mathrm{mM} & & \\ \begin{array}{lrrr}\mathrm{HCO}_{3}- \\ \mu \text { mol }\end{array} & -124 \pm 27 & -94 \pm 19 & 30 & <0.05 \\ \quad \text { mean } m M & 20.9 \pm 0.9 & 22.9 \pm 0.8 & 2 & <0.001 \\ \mathrm{pH} & & & & \\ \quad \text { Initial } & 7.43 \pm 0.01 & 7.46 \pm 0.01 & - & <0.02 \\ \Delta & -0.34 \pm 0.07 & -0.27 \pm 0.04 & 0.07 & <0.01 \\ \mathrm{PCO}_{2} & & & & \\ \text { Initial mm Hg } & 39.0 \pm 0.7 & 39.1 \pm 0.6 & - & \mathrm{NS} \\ \Delta m m \mathrm{Hg} & 16.5 \pm 4.8 & 13.7 \pm 4.9 & 2.8 & <0.01\end{array}$

(C)

Mean luminal Na concentration

\begin{tabular}{|c|c|c|c|c|}
\hline $\mathrm{HCO}_{3}-$ & $138 \pm 1 \mathrm{mM}$ & $11.1 \pm 2 \mathrm{mM}$ & & \\
\hline $\begin{array}{l}\text { umol } \\
\text { Mean } m M\end{array}$ & $\begin{array}{r}-174 \pm 36 \\
73.5 \pm 1.9\end{array}$ & $\begin{array}{r}-145 \pm 32 \\
74.7 \pm 2.2\end{array}$ & $\begin{array}{l}29 \\
1.2\end{array}$ & $\begin{array}{l}<0.05 \\
<0.05\end{array}$ \\
\hline \multicolumn{5}{|l|}{ pH } \\
\hline $\begin{array}{l}\text { Initial } \\
\Delta\end{array}$ & $\begin{array}{r}7.86 \pm 0.01 \\
-0.14 \pm 0.02\end{array}$ & $\begin{array}{r}7.88 \pm 0.01 \\
-0.12 \pm 0.03\end{array}$ & $\overline{0.02}$ & $\begin{array}{l}<0.01 \\
<0.05\end{array}$ \\
\hline \multicolumn{5}{|l|}{$\mathrm{PCO}_{2}$} \\
\hline $\begin{array}{l}\text { Initial } m m \mathrm{Hg} \\
\Delta \mathrm{mm} \mathrm{Hg}\end{array}$ & $\begin{array}{r}42.1 \pm 1.3 \\
6.5 \pm 2.0\end{array}$ & $\begin{array}{r}42.4 \pm 0.6 \\
5.4 \pm 1.8\end{array}$ & $\overline{1.1}$ & $\begin{array}{c}\text { NS } \\
<0.05\end{array}$ \\
\hline
\end{tabular}

* See footnote to Table II.

by a constant amount, about $30 \mu \mathrm{mol} \times(30 \mathrm{~min})^{-1} \times$ $\mathrm{gWW}^{-1}$. In addition, the $\Delta \mathrm{PCO}_{2}$ and $\Delta \mathrm{pH}$ were less in the solutions from which $\mathrm{Na}^{+}$was omitted.

When the initial lumen $\mathrm{HCO}_{3}^{-}$concentration was 25 $\mathrm{mM}$ (Table VB), the $\Delta \mathrm{Pco}_{2}$ was larger than when the initial concentration of $\mathrm{HCO}_{3}{ }^{-}$was either $15 \mathrm{mM}$ ( Table VA) or $80 \mathrm{mM}$ (Table VC). The reasons for this are not clear, but they do not affect the validity of the conclusions which are based on data with groups rather than between groups. 
TABLE VI

Effect of $25 \mathrm{mM} \mathrm{HCO}{ }^{-}$in Perfusion Fluid on the Magnitude of Luminal $\mathrm{PCO}_{2}(N=8)$

\begin{tabular}{cccc}
\hline \multirow{2}{*}{$\begin{array}{l}\text { Dependent } \\
\text { variable }\end{array}$} & \multicolumn{2}{c}{ Initial $\mathrm{HCO}_{3}$ - concentration } & \\
\cline { 2 - 3 } & $0 \mathrm{mM}$ & $25 \mathrm{mM}$ & $P$ \\
\hline $\mathrm{P}_{\mathrm{CO} 2}$ & & & \\
Initial $m m ~ H g$ & $\mathrm{Nil}$ & $\mathrm{Nil}$ & - \\
$\Delta m m \mathrm{Hg}$ & $30 \pm 2$ & $36 \pm 2$ & $<0.01$ \\
\hline
\end{tabular}

Study 5: effect of $\mathrm{HCO}_{3}{ }^{-}$in perfusion fluid on $\mathrm{PCO}_{2}$ and PD (Table VI)

Perfusion solutions 1 and 10 (Table I). $N=8$. When the perfusion fluid contained an initial $\mathrm{HCO}_{3}{ }^{-}$concentration of $25 \mathrm{mM}$, the increase in $\mathrm{PcO}_{2}$ was $6 \mathrm{~mm} \mathrm{Hg}$ larger than when $\mathrm{HCO}_{3}^{-}$was omitted. The mean $\mathrm{PD}( \pm \mathrm{SD})$ in eight rats when solutions with and without $\mathrm{HCO}_{3}^{-}$ were perfused were $-4.7 \mathrm{mV}( \pm 2.5)$, and $-5.4 \mathrm{mV}$ $( \pm 2.3)$. The differences were not significant.

Study 6: effect of enhanced $\mathrm{HCO}_{3}{ }^{-}$absorption on $\mathrm{PCO}_{2}$ ( Table VII)

Perfusion solutions 11 and 12 (Table I). $N=8$. When the initial concentration of $\mathrm{HCO}_{3}{ }^{-}$was increased from $20 \mathrm{mM}$ to $80 \mathrm{mM}$, net bicarbonate absorption more than doubled. However, there was no significant difference in the $\Delta \mathrm{PCO}_{2}$ in the two solutions.

Study 7: effect of buffering on $\mathrm{HCO}_{3}^{-}$absorption and $\mathrm{PCO}_{2}$ (Tables VIII and IX)

Perfusion solutions Tris study 13 and 14 (Table I). $N=8$. Phosphate study 14 and 15. $N=12$. As expected, when the perfusion fluid was buffered with Tris (Table VIII) or phosphate (Table IX), the $\mathrm{pH}$ fell less than in the unbuffered fluid. Buffering with Tris reduced $\mathrm{HCO}_{3}{ }^{-}$absorption by $18 \%$, but the reduction was not significant when phosphate was used. In both studies, however, buffering significantly reduced the $\triangle \mathrm{PcO}$.

\section{DISCUSSION}

Our studies demonstrate that a reduction in the concentration of sodium in fluid perfusing the lumen of the rat jejunum decreases $\mathrm{HCO}_{3}{ }^{-}$absorption by a constant amount, and that this decrease is not caused by concurrent changes in PD or water movement. The associated changes in $\mathrm{PCO}_{2}$ of the perfusion fluid suggest that the rate of $\mathrm{HCO}_{3}{ }^{-}$absorption decreases because the rate of $\mathrm{H}^{+}$secretion diminishes when the luminal $\mathrm{Na}^{+}$ concentration is reduced. The data supporting these conclusions are discussed below.
Effect of sodium, net water movement, and PD. When luminal sodium concentration was reduced, hydrogen ions accumulated in the lumen at a reduced rate, and bicarbonate absorption diminished (Table II). However, there were significant changes in two other factors that could have influenced the net movement of $\mathrm{H}^{+}$and $\mathrm{HCO}_{3}^{-}$: the $\mathrm{PD}$ became $8.7 \mathrm{mV}$ more positive in the lumen, and water moved into, rather than out of, the lumen. To estimate the influence of net water movement on transport of $\mathrm{HCO}_{3}^{-}$, a hypertonic solution was circulated through the lumen (Table III). Although the hypertonic solution caused a change in water movement greater than that induced by the low sodium solutions, the net movement of $\mathrm{HCO}_{3}^{-}$was unaffected. Hence, the net movement of water could not explain the reduction in $\mathrm{HCO}_{3}^{-}$absorption when the luminal sodium concentration was decreased. The influence of PD was more difficult to determine because it was not possible to induce $\mathrm{PD}$ changes of similar polarity and magnitude without reducing the intraluminal sodium concentration. We could, however, study the effect of changes of similar magnitude but opposite polarity. When the lumen was perfused with a solution containing sodium isethionate instead of sodium chloride, the lumen became more negative by $7.5 \mathrm{mV}$ (vs. $8.7 \mathrm{mV}$ more positive with low sodium solution). The net movement of potassium, a cation that is transported passively, reflected these changes. Net movement of potassium into the lumen diminished when the lumen became positive (Table II), and increased when the lumen became negative (Table IV). However, net movement of $\mathrm{HCO}_{3}{ }^{-}$did not change significantly when the lumen became more negative, so the effect on $\mathrm{HCO}_{8}^{-}$movement was not caused by changes in water movement or PD; the low luminal sodium concentration itself must have directly affected the processes that govern $\mathrm{HCO}_{3}{ }^{-}$absorption.

Omitting $\mathrm{Na}^{+}$from the perfusion fluid diminished the rate of $\mathrm{HCO}_{3}{ }^{-}$absorption by a constant amount of about $30 \mu \mathrm{mol} \times(30 \mathrm{~min})^{-1}$ regardless of whether the initial

TABLE VII

Effect of Increased Net Movement of $\mathrm{HCO}_{3}$ - on the Magnitude of Luminal $\mathrm{P}_{\mathrm{CO}_{2}}(N=8)$

\begin{tabular}{lccc}
\hline \multirow{2}{*}{$\begin{array}{c}\text { Dependent } \\
\text { variables }\end{array}$} & \multicolumn{2}{c}{ Initial $\mathrm{HCO}_{3}$ - concentration } \\
\cline { 2 - 3 } & $20 \mathrm{mM}$ & $80 \mathrm{mM}$ & $P$ \\
\hline $\mathrm{HCO}_{3}{ }^{-*}$ & & & \\
$\mu m o l$ & $-78.5 \pm 7.8$ & $-167 \pm 46.8$ & $<0.01$ \\
$\mathrm{P}_{\mathrm{CO}_{2}}$ & & & \\
Initial $m m ~ H g$ & $42 \pm 1$ & $41 \pm 1$ & NS \\
$\Delta m m ~ H g$ & $8 \pm 3$ & $11 \pm 2$ & NS \\
\hline
\end{tabular}

* See footnote to Table II. 
luminal $\mathrm{HCO}_{3}^{-}$concentration was 15,25 , or $80 \mathrm{mM}$ ( Table V). However, the percent of $\mathrm{HCO}_{3}{ }^{-}$absorption that was $\mathrm{Na}^{+}$dependent increased from $17 \%$ to $43 \%$ as the initial $\mathrm{HCO}_{3}{ }^{-}$concentration was reduced from 80 $\mathrm{mM}$ to $15 \mathrm{mM}$ and overall $\mathrm{HCO}_{3}{ }^{-}$absorption rate diminished. Thus, the mechanism of $\mathrm{HCO}_{3}^{-}$absorption that requires $\mathrm{Na}^{+}$becomes relatively more important as the concentration of $\mathrm{HCO}_{3}^{-}$in the lumen decreases below that of the plasma. Is $30 \mu \mathrm{mol} \times(30 \mathrm{~min})^{-1} \times$ $\mathrm{gWW}^{-1}$ the maximal rate of $\mathrm{Na}^{+}$-dependent $\mathrm{HCO}_{3}^{-}$absorption? Probably not, because the unidirectional flux of $\mathrm{Na}^{+},\left(J_{\mathrm{sm}} \mathrm{Na}^{+}\right)$, into the unstirred layer of fluid adjacent to the mucosa makes it impossible to create a luminal environment that is sodium-free. If sodium could be eliminated completely from the lumen, the reduction in $\mathrm{HCO}_{3}^{-}$absorption might be greater.

Could alterations in chloride movement have influenced the movement of hydrogen or bicarbonate ions when the luminal concentration of sodium was reduced? Mechanisms that could link the transport of chloride to the movement of $\mathrm{H}^{+}$or $\mathrm{HCO}_{3}^{-}$are: (a) transport of $\mathrm{H}^{+}$and $\mathrm{Cl}^{-}$into the lumen, or $(b)$ exchange of $\mathrm{Cl}^{-}$for luminal $\mathrm{HCO}_{3}^{-}$. When the concentration of sodium in the perfusion fluid was lowered, the blood-lumen concentration gradient of $\mathrm{Cl}^{-}$remained the same; hence the unidirectional movement of $\mathrm{Cl}^{-}$into the lumen could have been influenced only by a change in PD (Table II). Increased electropositivity of the lumen should have increased $\mathrm{Cl}^{-}$flux into the lumen and the net absorption of $\mathrm{HCO}_{3}^{-}$. Bicarbonate absorption diminished, however, despite the increased net movement of chloride into the lumen. It seems unlikely that $\mathrm{Cl}^{-}$transport influenced $\mathrm{HCO}_{3}{ }^{-}$absorption, but the possibility cannot be entirely excluded.

Mechanism of action of sodium. By what mechanism did the reduction in sodium concentration alter the

TABLE VIII

Effect of Buffering with Tris on Net Movement of $\mathrm{HCO}_{3}{ }^{-}$, and on Changes in Luminal $p H$ and $P_{C O_{2}}(N=8)$

\begin{tabular}{lrrr}
\hline \multirow{2}{*}{$\begin{array}{c}\text { Dependent } \\
\text { variables }\end{array}$} & Tris & Tris & \\
\cline { 2 - 3 } \multicolumn{1}{c}{ Not added } & Added & $P$ \\
\hline $\begin{array}{l}\mathrm{HCO}_{3}{ }^{-*} \\
\mu m o l\end{array}$ & $-82.0 \pm 12.7$ & $-67.0 \pm 15.6$ & $<0.05$ \\
$\mathrm{pH}$ & & & \\
Initial & $7.29 \pm 0.01$ & $7.29 \pm 0.01$ & $\mathrm{NS}$ \\
$\Delta$ & $-0.26 \pm 0.04$ & $-0.19 \pm 0.05$ & $<0.01$ \\
$\mathrm{P}_{\mathrm{CO} 2}$ & & & \\
Initial $\mathrm{mm} \mathrm{Hg}$ & $41.6 \pm 0.8$ & $42.6 \pm 0.8$ & $\mathrm{NS}$ \\
$\Delta m m \mathrm{Hg}$ & $8.1 \pm 2.4$ & $5.5 \pm 1.7$ & $<0.05$ \\
\hline
\end{tabular}

* See footnote to Table II.
TABLE IX

Effect of Buffering with Phosphate on Net Movement of $\mathrm{HCO}_{3}^{-}$ and on Changes in Luminal $p H$ and $P_{\mathrm{CO}_{2}}(N=8)$

\begin{tabular}{lccc}
\hline $\begin{array}{c}\text { Dependent } \\
\text { variables }\end{array}$ & Phosphate & Phosphate & \\
\cline { 2 - 3 } & Not added & Added & $P$ \\
\hline $\begin{array}{l}\mathrm{HCO}_{3}{ }^{-*} \\
\mu m o l\end{array}$ & $-87.1 \pm 9.8$ & $-77.4 \pm 13.5$ & NS \\
$\mathrm{pH}$ & & & \\
$\quad$ Initial & $7.27 \pm 0.0$ & $7.31 \pm 0.0$ & $<0.001$ \\
$\Delta$ & $-0.27 \pm 0.04$ & $-0.22 \pm 0.04$ & $<0.02$ \\
$\mathrm{P}_{\mathrm{CO}_{2}}$ & & & \\
Initial $m m ~ H g$ & $42.3 \pm 0.1$ & $43.1 \pm 0.1$ & $<0.05$ \\
$\Delta m m \mathrm{Hg}$ & $13.3 \pm 2.9$ & $10.1 \pm 2.4$ & $<0.05$ \\
\hline
\end{tabular}

* See footnote to Table II.

movement of hydrogen and bicarbonate ions? Was this caused primarily by a reduction in net movement of bicarbonate ions from the lumen, or by a reduction in net movement of hydrogen ions into the lumen? If bicarbonate leaves the lumen as the $\mathrm{HCO}_{3}^{-}$ion rather than as dissolved $\mathrm{CO}_{2}$, the increase in luminal $\mathrm{PCO}_{2}$ should be less in the solution that has the higher rate of bicarbonate loss, because removal of $\mathrm{HCO}_{3}{ }^{-}$ions forces the reaction, $\mathrm{OH}^{-}+\mathrm{CO}_{2} \leftrightarrows \mathrm{HCO}_{3}^{-}$, to the right. The $\Delta$ $\mathrm{PCO}_{2}$ was higher in the solution that had the higher rate of bicarbonate loss, however, implying that secretion of hydrogen ions into the lumen caused the net loss of bicarbonate, i.e., $\mathrm{H}^{+}$ions reacted with $\mathrm{HCO}_{3}{ }^{-}$to form $\mathrm{CO}_{2}$ which diffused from the lumen (Tables II and V).

Alternative explanations for changes in $\Delta \mathrm{PCO}_{2}$. Could some other process have caused these changes in $\Delta$ $\mathrm{PCO}_{2}$ ? If $\mathrm{HCO}_{3}{ }^{-}$ions were transported from the lumen into tissue fluids that were more acid than those of the lumen, the $\mathrm{PCO}_{2}$ of the tissue fluid would increase at a rate faster than $\mathrm{PCO}_{2}$ decreased in the lumen. The tissue $\mathrm{CO}_{2}$ might then diffuse back into the lumen and increase luminal $\mathrm{PCO}_{2}$. If such a process is important, enhancement of the mucosa-to-serosa flux of $\mathrm{HCO}_{3}^{-}\left(\mathrm{J}_{\mathrm{ms}} \mathrm{HCO}_{3}{ }^{-}\right)$ should increase $\triangle \mathrm{PcO}_{2}$. Assuming that the serosa-tomucosa flux of $\mathrm{HCO}_{3}^{-}\left(J_{\mathrm{sm}} \mathrm{HCO}_{3}^{-}\right)$remains constant when the $\mathrm{HCO}_{8}^{-}$concentration of the perfusion fluid is increased from $20 \mathrm{mM}$ to $80 \mathrm{mM}$, an increase in $\mathrm{HCO}_{3}{ }^{-}$ absorption must be caused by an augmented $J_{\mathrm{ms}} \mathrm{HCO}_{3}^{-}$. When net $\mathrm{HCO}_{3}{ }^{-}$absorption increased from 78.5 to 167 $\mu \mathrm{mol} \times(30 \mathrm{~min})^{-1} \times \mathrm{gWW}^{-1}, \Delta \mathrm{PCO}_{2}$ did not change significantly (Table VII). These findings demonstrate that it is possible to increase $\mathrm{HCO}_{3}^{-}$absorption (and $J_{\mathrm{ms}} \mathrm{HCO}_{3}{ }^{-}$) without increasing $\Delta \mathrm{PCO}_{2}$, and suggest that luminal $\mathrm{PCO}_{2}$ is not affected significantly by reactions of $\mathrm{HCO}_{3}^{-}$in mucosal tissue fluid. They support the view that the difference in $\Delta \mathrm{PCO}_{2}$ seen when low $\mathrm{Na}$ solutions 
are perfused arises because of reactions in the intestinal lumen, and not because of reactions of $\mathrm{HCO}_{3}{ }^{-}$in cells or interstitial fluid.

The effect of intraluminal buffering provides additional evidence that $\mathrm{CO}_{2}$ is generated in the lumen rather than in the surrounding tissues. Tris buffer reduced the absorption of $\mathrm{HCO}_{3}^{-}$(Table VIII). When $\mathrm{H}^{+}$ions moved into the luminal fluid, they could interact with either Tris or $\mathrm{HCO}_{3}{ }^{-}$. Because fewer $\mathrm{H}^{+}$ions reacted with $\mathrm{HCO}_{3}^{-}$in the Tris-containing solution, less $\mathrm{CO}_{2}$ was generated, and less $\mathrm{HCO}_{3}^{-}$was absorbed. Phosphate buffer had a similar effect on $\Delta \mathrm{Pco}_{2}$, but did not decrease $\mathrm{HCO}_{3}{ }^{-}$absorption significantly (Table IX). The reduction in $\Delta \mathrm{PCO}_{2}$ differs from the results of studies in man by Turnberg, Fordtran, Carter, and Rector (2) who found that the $\Delta \mathrm{PCO}_{2}$ increased when the perfusion solution was buffered with phosphate. In both studies the $\mathrm{PCO}_{2}$ changes are cited as evidence that hydrogen ions are secreted into the luminal fluid. The reasons for the difference are not clear. Because, in my studies, the reaction of $\mathrm{H}^{+}$with $\mathrm{HCO}_{3}^{-}$should have come to equilibrium in most of the luminal fluid by the time it entered the distal cannula, I believe that the above explanations for the changes in $\mathrm{PCO}_{2}$ are applicable.

Our view that the differences in $\Delta \mathrm{PCO}_{2}$ were caused by intraluminal reactions of $\mathrm{HCO}_{3}{ }^{-}$differs from that of Hamilton, Dawson, and Webb, who concluded from their studies in anesthetized dogs that luminal $\mathrm{PCO}_{2}$, "is not the result of chemical interaction postulated in previous studies, but rather of separate factors of tissue perfusion, $\mathrm{CO}_{2}$ diffusion, and $\mathrm{CO}_{2}$ production" (6). It is clear that in the absence of chemical reactions in the lumen, the $\mathrm{PCO}_{2}$ of luminal fluid will equilibrate with that of the adjacent mucosa; hence, factors of tissue perfusion, $\mathrm{CO}_{2}$ production, and diffusion will determine luminal $\mathrm{PCO}_{2}$. It is equally clear, however, that reaction of $\mathrm{HCO}_{3}^{-}$with $\mathrm{H}^{+}$in the lumen could contribute significantly, because luminal $\mathrm{PCO}_{2}$ does not equilibrate instantaneously with tissue $\mathrm{PCO}_{2}$. In the studies of Hamilton, et al., after gas mixtures with a $\mathrm{PCO}_{2}$ higher than steady-state mucosal $\mathrm{PCO}_{2}$ were infused into the canine intestinal lumen, luminal $\mathrm{PCO}_{2}$ values declined at an exponential rate to steady-state values with a half-time of about $5 \mathrm{~min}(6)$. Thus, luminal $\mathrm{Pco}_{2}$ in the steady state might be considerably higher than that of the basal $\mathrm{PcO}_{3}$ of surrounding tissues if $\mathrm{CO}_{2}$ were being generated in the lumen. In our study (Table VI) and that of Turnberg et al. (2), the addition of bicarbonate to jejunal fluid augmented $\Delta$ $\mathrm{PCO}_{2}$. If that additional $\mathrm{CO}_{2}$ was not generated in the lumen, it must have been caused by an enhanced rate of aerobic metabolism of mucosal cells, a reduced rate of $\mathrm{CO}$ a removal by the blood, or reaction of $\mathrm{HCO}_{3}{ }^{-}$with
$\mathrm{H}^{+}$in the fluid of the mucosal cells or interstitium. We have shown that the last possibility is unlikely (Table VII). The contrasting effects on luminal $\mathrm{PCO}_{2}$ of bicarbonate and the two buffers strongly suggest that the differences in $\Delta \mathrm{PcO}_{2}$ were not caused by changes in tissue perfusion or cell metabolism, because it is unlikely that tissue perfusion is decreased by bicarbonate and increased by phosphate and Tris, or that cell metabolism is enhanced by bicarbonate and diminished by phosphate and Tris. The changes in $\Delta \mathrm{PCO}_{2}$ are readily understood, however, if the reactions that influence luminal $\mathrm{PCO}_{2}$ occur in the lumen.

Contribution of $\mathrm{H}^{+}$secretion to $\mathrm{HCO}^{-}$absorption. What percent of $\mathrm{HCO}_{3}^{-}$absorption is caused by $\mathrm{H}^{+}$ secretion? The answer to this question may depend on the luminal concentration of $\mathrm{HCO}_{3}^{-}$. When the initial $\mathrm{HCO}_{3}{ }^{-}$concentration of luminal fluid was increased from 20 to $80 \mathrm{mM}$, the rate of $\mathrm{HCO}_{3}^{-}$absorption more than doubled, but $\Delta \mathrm{PCO}_{2}$ did not increase significantly $(P>0.1)$. This suggests that $\mathrm{H}^{+}$secretion is not the only mechanism of $\mathrm{HCO}_{3}{ }^{-}$absorption at the higher luminal $\mathrm{HCO}_{3}{ }^{-}$concentration, for, if it were, the $\Delta \mathrm{PCO}_{2}$ might have been greater in the perfusion fluid with the higher rate of $\mathrm{HCO}_{3}^{-}$absorption. It is clear that $\mathrm{H}^{+}$secretion causes some $\mathrm{HCO}_{3}{ }^{-}$absorption at higher luminal concentrations of $\mathrm{HCO}_{3}{ }^{-}$because omission of $\mathrm{Na}^{+}$from the perfusion solution reduces $\mathrm{CO}_{2}$ production $\left(\Delta \mathrm{PcO}_{2}\right)$ and absorption of $\mathrm{HCO}_{3}^{-}$(Table VC). When the initial luminal $\mathrm{HCO}_{3}{ }^{-}$concentration was $80 \mathrm{mM}$, omission of $\mathrm{Na}^{+}$from the perfusion fluid reduced $\mathrm{HCO}_{3}{ }^{-}$absorption by $17 \%$. Hence, at least $17 \%$ of $\mathrm{HCO}_{3}^{-}$absorption is caused by $\mathrm{H}^{+}$secretion (assuming that the effect of $\mathrm{Na}^{+}$ omission is mediated entirely by a reduction in $\mathrm{H}^{+}$secretion). With the available data, there is no way to estimate the maximal contribution of $\mathrm{H}^{+}$secretion to $\mathrm{HCO}_{3}{ }^{-}$absorption. In what other ways might $\mathrm{HCO}_{3}{ }^{-}$be absorbed? Passive diffusion of $\mathrm{HCO}_{3}^{-}$may contribute to absorption when $\mathrm{HCO}_{3}{ }^{-}$concentration in the lumen exceed those of plasma, but the failure of changes in $\mathrm{PD}$ to affect the $\mathrm{HCO}_{3}^{-}$movement provides some evidence against it. Perhaps the magnitude of change in $\mathrm{PD}$ was too small (about $8 \mathrm{mV}$ ) to effect a change in $\mathrm{HCO}_{3}{ }^{-}$ net movement that could be detected in our studies. These questions cannot be answered with the available data.

The addition of $\mathrm{HCO}_{3}^{-}$to a saline perfusion solution caused no significant change in $\mathrm{PD}$, implying that the processes that cause $\mathrm{HCO}_{3}^{-}$absorption do not generate a PD. What are examples of such a system? No PD would be generated if $\mathrm{Cl}^{-}$accompanies $\mathrm{H}^{+}$into the lumen, or if $\mathrm{Na}^{+}$leaves as $\mathrm{H}^{+}$enters. Our studies and those of Turnberg et al. (2) support the latter mechanism, but they do not exclude the possibility that secretion of 
$\mathrm{H}^{+}$and $\mathrm{Cl}^{-}$accounts for a fraction of $\mathrm{HCO}_{3}^{-}$absorption that may not be $\mathrm{Na}^{+}$dependent.

\section{CONCLUSIONS}

(a) When the concentration of $\mathrm{HCO}_{3}{ }^{-}$in the lumen is equal to or less than plasma, $\mathrm{H}^{+}$secretion causes some, and perhaps all, $\mathrm{HCO}_{3}^{-}$absorption.

(b) Some $\mathrm{H}^{+}$secretion requires $\mathrm{Na}^{+}$in the lumen. Perhaps all $\mathrm{H}^{+}$secretion requires luminal $\mathrm{Na}^{+}$, but this cannot be determined with the techniques used in this study because the diffusion of $\mathrm{Na}^{+}$into the lumen makes it impossible to create a luminal fluid that is free of $\mathrm{Na}^{+}$.

(c) The rate of $\mathrm{HCO}_{3}^{-}$absorption that is $\mathrm{Na}^{+}$dependent is constant regardless of whether the initial $\mathrm{HCO}_{3}^{-}$concentration of the perfusion fluid is smaller, larger, or equal to that of plasma. However, as the initial $\mathrm{HCO}_{3}^{-}$concentration of perfusion fluid is reduced, the percent of $\mathrm{HCO}_{3}^{-}$absorption that is $\mathrm{Na}^{+}$dependent increases because the rate of total $\mathrm{HCO}_{3}^{-}$absorption decreases.

(d) The nature of the mechanism for $\mathrm{HCO}_{3}^{-}$transport that is not $\mathrm{Na}^{+}$dependent remains to be determined.

\section{ACKNOWLEDGMENTS}

I gratefully acknowledge the skilled assistance of Mrs. Mary Denton.

This work was supported in part by U. S. Public Health Service Grants AM 09022 and AM 5390 from the National Institute of Arthritis and Metabolic Disease.

\section{REFERENCES}

1. Parsons, D. S. 1956. The absorption of bicarbonatesaline solutions by the small intestine and colon of the white rat. Q.J. Exp. Physiol. Cogn. Med. Sci. $41: 410$.

2. Turnberg, L. A., J. S. Fordtran, N. W. Carter, and F. C. Rector, Jr. 1970. Mechanism of bicarbonate absorption and its relationship to sodium transport in the human jejunum. J. Clin. Invest. 49: 548.

3. Fordtran, J. S., F. C. Rector, Jr., and N. W. Carter. 1968. The mechanisms of sodium absorption in the human small intestine. J. Clin. Invest. 47: 884.

4. McHardy, G. J. R., and D. S. Parsons. 1957. The absorption of water and salt from the small intestine of the rat. $Q$. J. Exp. Physiol. Cogn. Med. Sci. 42: 33.

5. Miller, D. L., and H. P. Schedl. 1970. Total recovery studies of nonabsorbable indicators in the rat small intestine. Gastroenterology. 58: 40.

6. Hamilton, J. D., A. M. Dawson, and J. P. W. Webb. 1968. Observations upon small gut "mucosal" $\mathrm{pO}_{2}$ and $\mathrm{PCO}_{2}$ in anesthetized dogs. Gastroenterology. 55: 52. 